\title{
Specific leaf area of European Larch (Larix decidua MiLL.)
}

\author{
Helga Fellner $^{1} \cdot$ Gerald F. Dirnberger $^{1} \cdot$ Hubert Sterba $^{1}$
}

Received: 1 September 2015/ Accepted: 22 January 2016/Published online: 16 February 2016

(C) The Author(s) 2016. This article is published with open access at Springerlink.com

\begin{abstract}
Key message The specific leaf area of European larch depends on branch height and canopy depth, indicating that both, the effect of hydraulic limitations and low water potentials in greater branch heights, and light availability affect specific leaf area.

Abstract Specific leaf area (SLA) is defined as the ratio between projected leaf area and needle dry mass. It often serves as parameter in ecosystem modelling as well as indicator for potential growth rate. We explore the SLA of European larch (Larix decidua) and the most important factors which have an influence on it. Data were collected from eight stands in Styria, Austria. The stands varied in age, elevation and species mixture. Four stands were pure larch stands with only minor proportions of Norway spruce (Picea abies), whereas the other four were mixed stands of larch and spruce. In each stand 15 representative sample trees were felled. The crown of each sample tree was divided into three sections of equal length and in each section a random sample of needles was taken for determining projected leaf area and dry mass of 50 needles. The mean SLA of larch was established to be $117 \mathrm{~cm}^{2} \mathrm{~g}^{-1}$ with a standard deviation of $\pm 27.9 \mathrm{~cm}^{2} \mathrm{~g}^{-1}$. SLA varies within the crown, but neither between different mixtures nor years of observation nor social position of the trees. A mixedeffects model, with the plots as random effect, revealed that SLA of larch decreased with increasing branch height
\end{abstract}

Communicated by R. Grote.

Helga Fellner

Helga.Fellner@boku.ac.at

1 Department of Forest and Soil Science, University of Natural Resources and Life Sciences (BOKU), Peter Jordan Strasse 82, 1190 Vienna, Austria $(p=0.0012)$ and increased with increasing canopy depth $(p=0.029)$. We conclude that both the hydraulic limitations due to low water potentials in greater branch heights and light availability affect specific leaf area.

Keywords Larix decidua MiLl. · Specific leaf area (SLA) - Mixed stands - European larch · Branch height · Canopy depth

$\begin{array}{ll}\begin{array}{l}\text { Abbreviations } \\ \text { SLA }\end{array} & \begin{array}{l}\text { Specific leaf area (leaf mass per projected } \\ \left(\mathrm{cm}^{2} \mathrm{~g}^{-1}\right)\end{array} \\ \text { DBH }(\mathrm{cm}) & \begin{array}{l}\text { Diameter at breast height }(1.3 \mathrm{~m}) \\ \text { CS }\end{array} \\ & \begin{array}{l}\text { Crown section (lower, middle, upper crown } \\ \text { section) }\end{array} \\ \text { ST } & \text { Stand type (mixed or pure) } \\ \text { SOC } & \text { Social position (dominated, intermediate, } \\ & \text { dominant) }\end{array}$

\section{Introduction}

Due to its characteristics and ecological value, larch is a highly prevailing tree species especially in mountainous areas. European larch (Larix decidua MiLL.) can be found in the northern boreal forests from the lowlands to the mountains, whereas in the southern extension it occurs only in the mountainous regions. It is a significant timberline species in Central Europe. In Austria it accounts for $4 \%$ of tree species distribution, in elevations above $900 \mathrm{~m}$; however, its proportion is already $8 \%$. This still may sound little compared to the $53 \%$ domination of Norway spruce, but the presence of European larch is an important admixture for enrichment of the species diversity and 
stabilisation of mountain forests with regard to landslides. It serves as a resilient tree species in protective forests as well as pioneer tree species for re-colonisation on large natural disturbances. Compared to other conifers, larch is very shade intolerant, but can cope with poor soils and little water availability (Schober 1949; Mayer 1977; Englisch et al. 2011; Bundesforschungszentrum für Wald (BFW) 2013).

Another feature of European larch is that it has long shoot needles as well as short shoot needles. They look different in their phenology. Needles on short shoots are arranged in little clusters of 20-40 needles, whereas needles on long shoots are arranged alternately. Needles are shed in autumn, which is unique among European conifers (Geburek 2002).

Specific leaf area (SLA) is defined as the ratio between projected leaf area and needle dry mass $\left(\mathrm{cm}^{2} \mathrm{~g}^{-1}\right)$. Research shows that SLA reacts very sensitively to changes of the availability of resources, e.g. light, humidity and nutrition (Gholz et al. 1976; Smith et al. 1981; Matyssek 1986; Klinka et al. 1992; Wilson et al. 1999; Marshall and Monserud 2003; White and Scott 2006; Poorter et al. 2009)

SLA is important for estimating the leaf area of whole trees (Monserud and Marshall 1999; Xiao et al. 2006) and it is positively and linearly correlated to relative growth rate (Poorter et al. 2009). Although it is an often used parameter for ecosystem functions, its reciprocal value, leaf mass per area (LMA), is also used because it correlates positively and linearly with additional investments in the leaf thickness (Poorter et al. 2009). Specific leaf weight is also highly correlated with the annual photosynthetic rate (Oren et al. 1986; Wilson et al. 1999; Cornelissen et al. 2003; Poorter et al. 2009).

SLA increases with decreasing light conditions, and thus with canopy depth. Stand structure has a similar influence on the light conditions, and therefore also affects SLA (Del Rio and Berg 1979; Abrams and Kubiske 1990; Chen and Klinka 1998; Tardieu et al. 1999; Bond et al. 1999; Nagel and O'Hara 2001; Poorter et al. 2006).

Less shade tolerant species have a lower SLA and are less flexible in physical leaf properties than shade tolerant tree species (Abrams and Kubiske 1990; Smith et al. 1991; Chen et al. 1996; Chen 1997; Bond et al. 1999; Marshall and Monserud 2003; Xiao et al. 2006). Conversely, high SLA can be found at shade tolerant tree species (Cornelissen et al. 2003; Lichtenthaler et al. 2007; Perrin and Mitchell 2013).

Light conditions are not the only reason for high or low SLA; it also depends on the longevity of leaves (Gholz et al. 1976; Del Rio and Berg 1979) and differs between evergreen and deciduous trees (Gower and Richards 1990; Withington et al. 2006).
The availability of nutrients also influences SLA. In environments that are well-supplied with nutrients, species tend to have a higher SLA than in nutrient-poor environments (Pierce et al. 1994; Cornelissen et al. 2003; White and Scott 2006; Poorter et al. 2009). Withington et al. (2006) found positive relationships between SLA, leaf nitrogen and tissue density of the roots while there was a negative relationship with root production when studying six Pinacea, among them one plot with European larch.

SLA has also been found to be affected by hydraulic limitations and lower water potentials in greater branch heights, due to the pull of the water column (Chen 1997; Tardieu et al. 1999; Nagel and O'Hara 2001; Marshall and Monserud 2003; Koch et al. 2004).

Compared to other conifer tree species such as Norway spruce (Picea abies (L.) H. Karst.) with a mean SLA of $45.8 \mathrm{~cm}^{2} \mathrm{~g}^{-1}$ (Oleksyn et al. 1998) to $50 \mathrm{~cm}^{2} \mathrm{~g}^{-1}$ (Hager and Sterba 1985), Scots pine (Pinus sylvestris L.) with $43.8 \mathrm{~cm}^{2} \mathrm{~g}^{-1}$ (Xiao et al. 2006), Douglas-fir (Pseudotsuga menziesii (Mirb.) Franco var. glauca) with $34.3 \mathrm{~cm}^{2} \mathrm{~g}^{-1}$, Western white pine (Pinus monticola Dougl. Ex D. Don) with $41.4 \mathrm{~cm}^{2} \mathrm{~g}^{-1}$ and Ponderosa pine (Pinus ponderosa Dougl. Ex. P. \& C. Laws.) with $25.8 \mathrm{~cm}^{2} \mathrm{~g}^{-1}$ (Marshall and Monserud 2003), the specific leaf area of European larch is expected to be two to four times higher (see e.g. Gower and Richards 1990; Wieser et al. 2013). Conversely for two more flat-needles species Lichtenthaler et al. (2007) report SLAs of $60-80 \mathrm{~cm}^{2} \mathrm{~g}^{-1}$ for young Abies alba (Mill.) and Perrin and Mitchell (2013) even 100-200 $\mathrm{cm}^{2}$ $\mathrm{g}^{-1}$ for Taxus baccata (L.) saplings.

The objective of this investigation is (1) to find the average SLA of larch, and (2) to investigate the dependence of SLA on site-, stand- and tree characteristics and especially try to evaluate its dependence on light conditions versus its dependence on hydrologic limitations.

\section{Materials and methods}

\section{Study area and study design}

The observed plots are located in the northern part of the eastern intermediate Alps near Leoben in Styria, Austria. The coordinates are $47^{\circ} 26^{\prime}$ east latitude and $15^{\circ} 05^{\prime}$ north longitude at an altitude of 900-1300 m above sea level. The mean annual temperature is $6.1^{\circ} \mathrm{C}$ and the mean annual precipitation is $1000 \mathrm{~mm}$ (ZAMG 2014-observation period between 1971 and 2000). The maximum rainfall occurs in July. The soils are mostly poor podzolic brown soils (Kilian et al. 1994). All the stands were located in steep terrain (slope 50-70\%) and exposed to Northwest to West. The mean annual volume increment at age 100 [estimated according to Marschall (1975)], only varies 
between 8 and $9 \mathrm{~m}^{3}$ per year and hectare, indicating medium site quality.

Data were collected in four stands during the growing season of 2012 and in four more stands in 2013. The stands varied in age. In each year, 2012 and 2013, we selected two nearly pure larch stands, and two other stands with mixtures of Norway spruce and European larch. In each stand a plot was established (for plot size see Table 1). In these plots a full inventory was performed, determining tree species, diameter at breast height $(\mathrm{DBH})$, tree height and height to the crown base.

The larches of each plot were classified into three social classes (SOC in Abbreviations) of equal frequency (dominated, intermediate and dominant) by their DBH. Five representative trees per class were selected, excluding trees on plot edges or with irregular crown shape. Overall, this resulted in 15 sample trees per plot. In sum, there were 120 sample trees for both years (60 in mixed stands and 60 in pure stands). The selection process was crucial to ensure a broad variation of growing conditions of the collected needles for further analyses. These sample trees were felled and age was determined by counting the tree rings of the stump. The crown of each sample tree was divided into three sections of equal length (CS in Abbreviations). From each crown third a representative branch was chosen and a handful twigs were collected. From these twigs 50 needles were picked for weighing and determining the leaf area. In 2013 we also collected short and long shoot needles separately from the same trees and in the same locations to test if there were differences between the two kinds of needles in regard of SLA. All 50 needles together were scanned immediately after their collection in the field and surveyed with a raster graphics editor [Adobe (2014) Photoshop $\left.\mathrm{CS} 4{ }^{\circledR}\right]$ subsequently in the laboratory, resulting in the projected leaf area. These needle samples were dried to constant mass at $105^{\circ} \mathrm{C}$ and weighed (Table 1).
For describing the light availability of each sample we used the following calculation. As shown in Fig. 1, first, the height of the largest tree in each plot was searched. From this maximum tree height, the branch height of the sampled branch in each individual sample tree was subtracted, resulting in the canopy depth as a proxy for the light availability.

\section{Statistical analysis}

After data collection and calculation of the SLA for all samples, a series of tests were conducted. First of all, a pairwise $t$ test was run to search for differences of the SLA of long and short shoot needles. Then one-way ANOVAs were performed for detecting SLA differences between the main factors, year of sampling, stand type (pure or mixed), social position of the tree, and crown section within the trees. Because of the unbalanced and hierarchical data structure we used mixed-effects models approach for testing for influential variables all together, with the plots and the trees within the plot as random effects $(u)$ and the fixed effects $(x)$ altitude above sea level, year of sampling, quadratic mean diameter, age and mixture, DBH, tree height, branch height and canopy depth.

$$
\begin{aligned}
y= & a_{0}+a_{1} x_{1}+a_{2} x_{2}+\cdots+a_{n} x_{n}+b_{1} x_{1} x_{2}+b_{2} x_{1} x_{3} \\
& +\cdots+b_{n n} x_{n-1} x_{n}+u_{\text {tree }}+u_{\text {plot }}
\end{aligned}
$$

where $a_{i}$ are the coefficients for the main effects, $x_{i}$, and $b_{i}$ the coefficients for the respective interaction terms, $x_{i} x_{j}$.

All statistical calculations were performed in the program R (R Development Core Team 2013), the mixedeffects models were calculated with the function lme. For comparing the different mixed-effects models we used the procedure after Pinheiro and Bates (2004, p. 159), where a likelihood ratio test was used.
Table 1 Stand level characteristics and plot attributes

\begin{tabular}{lllllllll}
\hline $\begin{array}{l}\text { Plot } \\
\text { number }\end{array}$ & Year & $\begin{array}{l}\text { Stand- } \\
\text { type }\end{array}$ & $\begin{array}{l}\text { Plot size } \\
(\text { ha })\end{array}$ & $\begin{array}{l}\text { Age } \\
(\text { years })\end{array}$ & $\begin{array}{l}\text { QMD } \\
(\mathrm{cm})\end{array}$ & $\begin{array}{l}H_{\text {dom }} \\
(\mathrm{m})\end{array}$ & $\begin{array}{l}\text { Stocking } \\
\text { degree }\end{array}$ & $\begin{array}{l}\text { Norway spruce } \\
(\%)\end{array}$ \\
\hline 2 & 2012 & Mixed & 0.266 & $44( \pm 5)$ & 27.3 & 21.5 & 1.162 & 53.6 \\
3 & 2012 & Pure & 0.250 & $46( \pm 5)$ & 22.8 & 21.2 & 1.731 & 13.2 \\
5 & 2013 & Mixed & 1.166 & $98( \pm 16)$ & 36.4 & 35.0 & 0.768 & 33.5 \\
6 & 2013 & Pure & 0.681 & $92( \pm 3)$ & 30.7 & 31.7 & 0.891 & 12.0 \\
8 & 2012 & Mixed & 0.328 & $131( \pm 13)$ & 44.5 & 33.5 & 1.263 & 49.3 \\
9 & 2012 & Pure & 1.154 & $147( \pm 6)$ & 46.0 & 39.3 & 0.874 & 14.2 \\
11 & 2013 & Mixed & 1.289 & $186( \pm 6)$ & 48.3 & 31.8 & 0.994 & 33.1 \\
12 & 2013 & Pure & 1.110 & $96( \pm 9)$ & 35.6 & 32.2 & 0.790 & 0.2 \\
\hline
\end{tabular}

Note that the missing plot numbers, referring to the established pure Norway spruce stands, were not used in this investigation. The age is the average age of the sample trees, in brackets, the standard deviation. QMD is the quadratic mean diameter. $H_{\text {dom }}$ the dominant height, i.e. the mean height of the largest 100 trees per ha. Stocking degree is calculated according to the yield tables by Marschall (1975). The proportion of spruce is in $\%$ of the crown projection area in the layer above $60 \%$ of the maximum tree height 
Table 2 Tree characteristics of all larch sample trees in each plot, with arithmetic means $( \pm$ standard deviation) of diameter at breast height $(\mathrm{DBH})$, crown ratio $(\mathrm{CR})$, branch height $(\mathrm{BH})$, canopy depth $(\mathrm{CD})$ and specific leaf area (SLA)

\begin{tabular}{|c|c|c|c|c|c|}
\hline Plot number & $\mathrm{DBH}(\mathrm{cm})$ & CR (\%) & $\mathrm{BH}(\mathrm{m})$ & $\mathrm{CD}(\mathrm{m})$ & SLA $\left(\mathrm{cm}^{2} \mathrm{~g}^{-1}\right)$ \\
\hline 2 & $25.7( \pm 8.2)$ & $65.5( \pm 8.5)$ & $11.9( \pm 3.6)$ & $11.4( \pm 3.7)$ & $144.9( \pm 33.8)$ \\
\hline 3 & $22.2( \pm 6.3)$ & $49.2( \pm 9.4)$ & $14.1( \pm 2.6)$ & $11.5( \pm 2.6)$ & $120.8( \pm 36.6)$ \\
\hline 5 & $37.3( \pm 10.2)$ & $32.1( \pm 5.1)$ & $28.3( \pm 3.8)$ & $14.7( \pm 3.8)$ & $107.7( \pm 15.9)$ \\
\hline 6 & $32.8( \pm 6.0)$ & $36.7( \pm 7.0)$ & $25.6( \pm 3.5)$ & $11.3( \pm 3.5)$ & $135.7( \pm 23.0)$ \\
\hline 8 & $45.6( \pm 8.3)$ & $49.3( \pm 9.3)$ & $23.8( \pm 4.0)$ & $14.7( \pm 4.0)$ & $100.0( \pm 22.4)$ \\
\hline 9 & $45.3( \pm 9.3)$ & $52.2( \pm 8.9)$ & $28.0( \pm 5.5)$ & $17.1( \pm 5.5)$ & $106.6( \pm 19.0)$ \\
\hline 11 & $46.6( \pm 8.2)$ & $39.9( \pm 5.0)$ & $24.1( \pm 3.4)$ & $13.1( \pm 3.4)$ & $119.7( \pm 14.7)$ \\
\hline 12 & $36.9( \pm 9.1)$ & $40.6( \pm 5.7)$ & $24.2( \pm 4.1)$ & $15.3( \pm 4.1)$ & $106.2( \pm 14.2)$ \\
\hline Overall & $36.5( \pm 11.8)$ & $45.7( \pm 12.4)$ & $22.5( \pm 6.9)$ & $13.6( \pm 4.3)$ & $117.7( \pm 27.9)$ \\
\hline
\end{tabular}

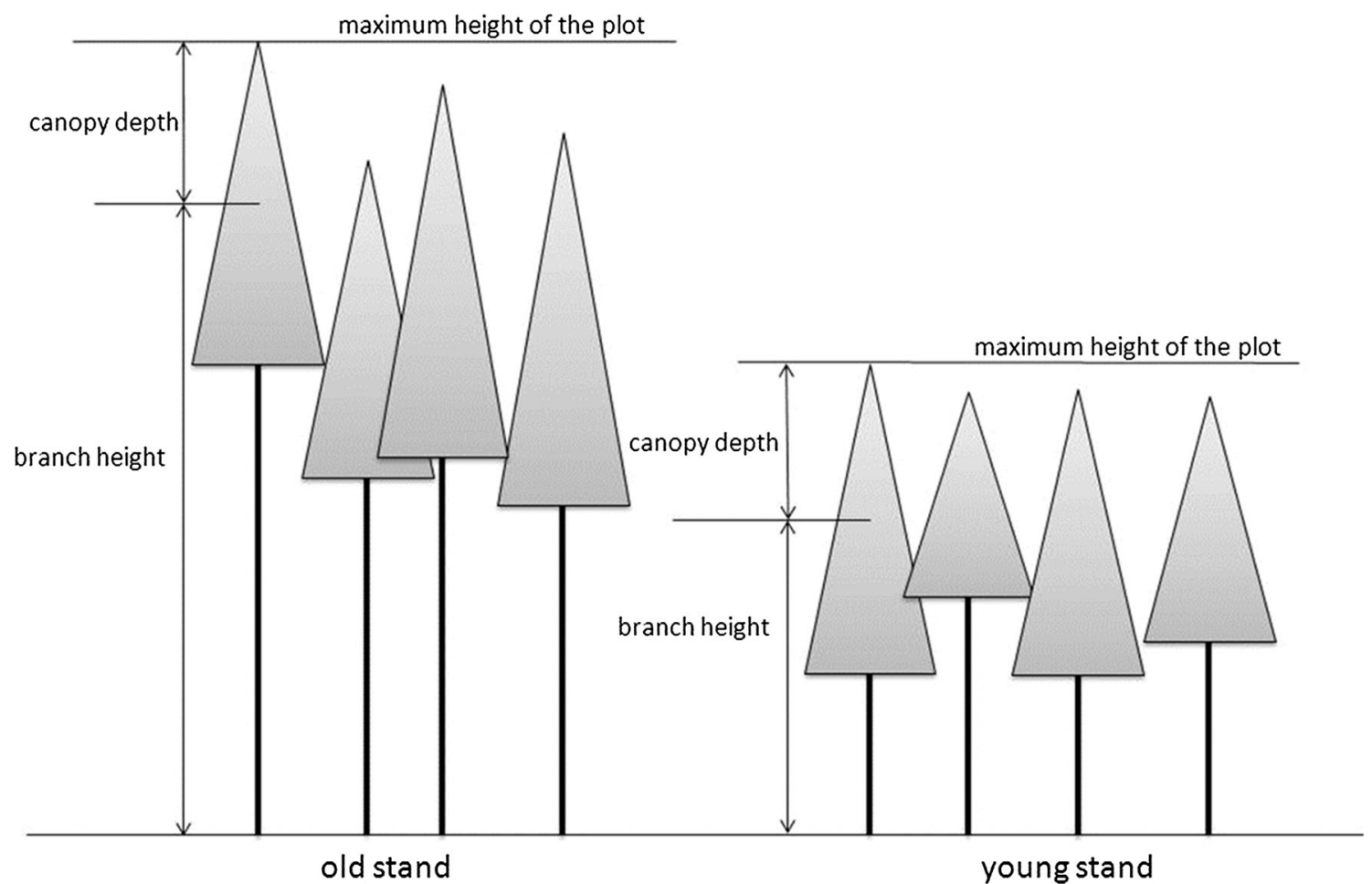

Fig. 1 Definition of branch height and canopy depth

\section{Results}

The overall arithmetic mean SLA resulted in $117 \mathrm{~cm}^{2} \mathrm{~g}^{-1}$ with a standard deviation of $\pm 27.9 \mathrm{~cm}^{2} \mathrm{~g}^{-1}$ (Table 2).

\section{Variation of SLA}

The SLA decreased within the crown from the bottom to the top, regardless of the recording year. No SLA differences were detected between pure and mixed stands as well as between the social positions (Table 3 ).

The random effect of the trees within the plot was not significant and was not considered anymore in further data analysis.

Note that in Tables 2 and 3 the arithmetic means are reported. Kumer (2015, personal communication) found that $26 \%$ of the leaf mass is located in the lower crown third, $42 \%$ in the middle crown third and $32 \%$ in the 
Table 4 Summary of results from the final model (see Eq. 2), with the coefficients, their standard error (SE), degrees of freedom of the denominator (DF) and $p$ value

\begin{tabular}{lrlll}
\hline Fixed effect & Coefficient & SE & DF & $p$ value \\
\hline Intercept & 5.258888 & 0.3873 & 350 & 0.0000 \\
ln(branch height) & -0.272955 & 0.0836 & 350 & 0.0012 \\
ln(canopy depth) & 0.123760 & 0.0565 & 350 & 0.0290 \\
\hline
\end{tabular}

upper crown third. Considering the different proportion of leaf mass in the three crown thirds, the weighted mean specific leaf area is $\overline{S L A}_{\text {weighted }}=117.1 \mathrm{~cm}^{2} \mathrm{~g}^{-1}$.

An overall analysis with the natural logarithm of SLA as dependent variable, with the plot as random effect and all other variables and their interactions as fixed effects (Eq. 1) revealed no significant relationship at all. Nonsignificant variables were then stepwise eliminated from our analysis and parameters were re-estimated. Finally, only the variables, branch height and canopy depth were significant $(\alpha=0.05)$.

The final equation is thus:

$$
\begin{aligned}
\ln (\mathrm{SLA})\left[\mathrm{cm}^{2} \mathrm{~g}^{-1}\right]= & a+b \ln (\text { branchheight }[m]) \\
& +c \ln (\text { canopydepth }[m])+u
\end{aligned}
$$

with $u$, the random effect of the plots (standard deviation $= \pm 0.119), a$ the intercept and $b$ and $c$, the estimated coefficients of the fixed effects, given in Table 4. About $22 \%$ of the variation was explained by this equation.

Besides these two variables, canopy depth and branch height, none of the others added significant information for SLA, indicating that the effects of age, altitude above sea level, $\mathrm{DBH}$, tree height, etc. and their interactions are sufficiently described by the two variables left in the equation.

Please note that within a plot, canopy depth and branch height are strictly linearly related. Over all plots, however, they are nearly uncorrelated $\left(R^{2}=0.053\right)$ because of the different canopy heights (maximum tree height) of the plots (see Fig. 1; Table 1). Thus for the whole dataset, the effects of canopy depth and branch height are not confounded.

\section{Short shoot needles versus long shoot needles}

As mentioned before we investigated differences between the SLA of the needles on short and long shoots from the samples of 2013. As a result, the needles on the short shoots had an approximately $4 \mathrm{~cm}^{2} \mathrm{~g}^{-1}$ higher SLA than those on the long shoots $(p<0.001)$. These differences were the most obvious in the lower section of the crown, but not significant in the uppermost crown section (Table 5). 
Table 5 The mean differences between specific leaf area ( $\triangle$ SLA) of the short and the long shoot needles: $\triangle \mathrm{SLA}=\mathrm{SLA}_{\text {short-shoot - }}$ $\mathrm{SLA}_{\text {long-shoot }}\left(\mathrm{cm}^{2} \mathrm{~g}^{-1}\right)$ and the standard deviations in different crown sections

\begin{tabular}{llll}
\hline & \multicolumn{2}{l}{ Crown section } & \\
\cline { 2 - 4 } Upper & $\begin{array}{l}\text { Lower } \\
\text { All }\end{array}$ & & Middle \\
\hline Mean & $8.46^{\mathrm{a}}$ & $5.56^{\mathrm{ab}}$ & \\
$-0.644^{\mathrm{b}}$ & 4.46 & & \pm 13.7 \\
$\begin{array}{l}\text { Standard } \\
\quad \text { deviation }\end{array}$ & \pm 17.8 & \pm 17.7 & \\
\pm 16.9 & & & \\
$p(>t)$ & 0.00048 & 0.0181 & 0.7173 \\
0.00049 & & & \\
\hline
\end{tabular}

The last line indicates the results of $t$ tests for mean difference being 0 The means that are not significantly different (Scheffée-Test) are indicated by the same letter

\section{Discussion}

European larch occupies a special position among European conifers with regard to its deciduous behaviour. The high value of SLA of our study of $117 \mathrm{~cm}^{2} \mathrm{~g}^{-1}$ with a standard deviation of $\pm 27.9 \mathrm{~cm}^{2} \mathrm{~g}^{-1}$ is supported by the results of other studies, which have also found high values for SLA of larch. Gower and Richards (1990) report an SLA of European larch of $123 \mathrm{~cm}^{2} \mathrm{~g}^{-1}$, whereas Matyssek and Schulze (1987a, b) state an average mass per all-sided leaf area of $4.13 \mathrm{mg} \mathrm{cm}^{-2}$, resulting in a SLA (which is based on projected leaf area) of $121 \mathrm{~cm}^{2} \mathrm{~g}^{-1}$.

Wieser et al. (2013) studied the long-term impact of ozone on photosynthesis of tree species at the timber line. They conclude that the high sensitivity of European larch to $\mathrm{O}_{3}$ is a result of its high SLA of $125 \mathrm{~cm}^{2} \mathrm{~g}^{-1}$.

An older investigation by Burger (1945) with a sample of about 100 individuals of European larch, scattered all over Switzerland reports an average SLA of $152 \mathrm{~cm}^{2} \mathrm{~g}^{-1}$. With this exception, our result deviates only negligibly from previous reports, e.g. Gower and Richards (1990), Matyssek and Schulze (1987a, b) and Wieser et al. (2013).

\section{Variation of SLA}

SLA varies within the crown, but not between stand type, data recording years and social position.

The variation within the crown can be confirmed with numerous studies, which have well documented the high influence of the needle/leaf position in other tree species.

Most of the authors interpret this result as an expression of the investigated species' ability to cope with changing light. Hager and Sterba (1985) found this for Norway spruce; Abrams and Kubiske (1990) for different hardwood

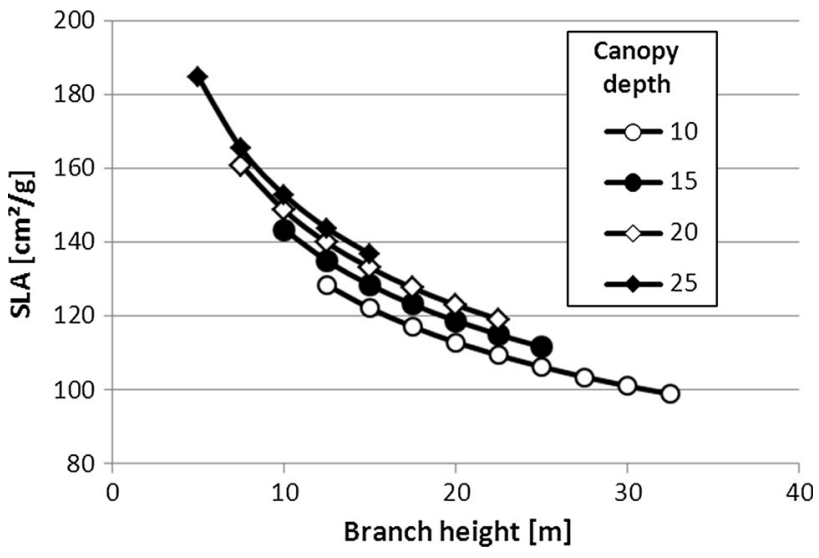

Fig. 2 Specific leaf area depending on the branch height and canopy depth $(10,15,20$ and $25 \mathrm{~m})$ for European larch

species; Chen and Klinka (1998) for Larix orientalis; Chen (1997) and Bond et al. (1999) for Pseudotsuga menziesii and Pinus ponderosa.

Poorter et al. (2006) found the response of larch to lower irradiance smallest compared to other tree species, and Marshall and Monserud (2003) did not find a strong shading effect on SLA. However, understanding canopy depth as a proxy for light availability within the crown, we could proof such an influence on SLA $(p=0.0290)$. A review, dealing with the within-canopy variations in leaf structural, chemical and physiological traits, reports on the results of 292 studies for 304 taxa and concludes that the light-dependent increases in foliage photosynthetic capacity per area are surprisingly similar in different plant functional types. They however differ fundamentally in the way of their control by constituent traits (Niinemets et al. 2015). Unfortunately this review does not comprise any study dealing with European larch and only four out of 292 studies dealing with other larch species.

However, we also found that branch height had an additional significant influence on SLA $(p=0.0032)$. This agrees well with Marshall and Monserud's (2003) interpretation of the influence of the gravitational component of the water potential, falling with increasing branch height (Fig. 2) for three different tree species in Idaho as a cause for the decrease of SLA from the bottom to the top of the crown. This interpretation may also explain the frequently found effect of drought on decreasing SLA (e.g. Phillips and Riha 1993; van Hees 1997; Ibrahim et al. 1998; Myers et al. 1998). Since European larch (together with Norway spruce) has been found most susceptible to drought (Lévesque et al. 2013), this additionally may explain why we found this relationship highly significant.

The $R^{2}$, for the mixed-effects model was quite weak $\left(R^{2}=0.22\right)$. A reason could be the rather small variation of our SLA (coefficient of variation $= \pm 24 \%$ ), due to the 
absence of shade needles. This compares well to the study of Marshall and Monserud (2003) where the $R^{2}$ for the relationship between branch height and SLA is also weakest for ponderosa pine $\left(R^{2}=0.22\right)$, where the total variation of SLA is smallest (coefficient of variation $=18 \%$ ).

When comparing short shoot needles with long shoot needles, we found a slightly higher average SLA at short shoot needles than on long shoot needles (about $4 \mathrm{~cm}^{2} \mathrm{~g}^{-1}$; $p \ll 0.001)$. Although highly significant, the difference between the SLA of short shoot needles and the SLA of long shoot needles was only about $3 \%$. Neglecting this difference is even more justified because Burger (1945) claims that larch has much more short than long shoot needles, and therefore the needles on long shoots may be neglected.

\section{Conclusions}

- Mean SLA is approximately $117 \mathrm{~cm}^{2} \mathrm{~g}^{-1}$. Compared to other conifer tree species like Norway spruce or Scots pine it is two to four times higher. This is supported by the studies of Gower and Richards (1990), Matyssek and Schulze (1987a, b) and Wieser et al. (2013).

- Branch height as well as canopy depth have a significant influence on the SLA of European larch. This indicates that the hydraulic limitations and lower water potentials in greater branch heights, as well as the decrease in light availability with increasing crown depth are influencing the SLA of European larch.

- The SLA of short and long shoot needles differs statistically significant, but this difference is only about $3 \%$.

\section{Authors contribution statement All authors contributed equally.}

\begin{abstract}
Acknowledgments The authors acknowledge the financial support of the Austrian Science Fund (FWF) under project No. P24433-16. We are also thankful to the Leobner Realgemeinschaft, who placed their sites at our disposal and supported our fieldwork. We want to express our gratitude to Martin Gspaltl, Josef Paulič, Angela Kumer, Arnold Reichl, Harald Bretis, Johannes Pretscherer, Markus Würkner, Wolfgang Tomasin, Jan-Peter George, Philipp Gruber, Christian Freinschlag and Jörg Zisser for their support during the fieldwork.
\end{abstract}

\section{Compliance with ethical standard}

Conflict of interest The authors declare that they have no conflict of interest.

Open Access This article is distributed under the terms of the Creative Commons Attribution 4.0 International License (http://crea tivecommons.org/licenses/by/4.0/), which permits unrestricted use, distribution, and reproduction in any medium, provided you give appropriate credit to the original author(s) and the source, provide a link to the Creative Commons license, and indicate if changes were made.

\section{References}

Abrams MD, Kubiske ME (1990) Leaf structural characteristics of 31 hardwood and conifer tree species in Central Wisconsin: influence of light regime and shade-tolerance rank. For Ecol Manage 31:245-253

Adobe (2014) Photoshop CS4. http://www.adobe.com/de/products/ photoshop-elements.html/

Bond BJ, Farnsworth BT, Coulombe RA, Winner WE (1999) Foliage physiology and biochemistry in response to light gradients in conifers with varying shade tolerance. Oecologia 120:183-192. doi: $10.1007 / \mathrm{s} 004420050847$

Bundesforschungszentrum für Wald (BFW) (2013) Österreichische Waldinventur. http://bfw.ac.at/rz/wi.home

Burger H (1945) Holz, Blattmenge und Zuwachs VII. MitteilungDie Lärche, XXIV Band. Kommisionsverlag von Beer and Cie., Buchhandlung, Zürich

Chen HYH (1997) Interspecific responses of planted seedlings to light availability in interior British Columbia: survival, growth, allometric patterns, and specific leaf area. Can J For Res 27:1383-1393. doi:10.1139/cjfr-27-9-1383

Chen HYH, Klinka K (1998) Survival, growth, and allometry of planted Larix occidentalis seedlings in relation to light availability. For Ecol Manage 106:169-179. doi:10.1016/S03781127(97)00309-5

Chen HYH, Klinka K, Kayahara GJ (1996) Effects of light on growth, crown architecture, and specific leaf area for naturally established Pinus contorta var. latifolia and Pseudotsuga menziesii var. glauca saplings. Can J For Res 26:1149-1157

Cornelissen JHCA, Lavorel SB, Garnier EB et al (2003) A handbook of protocols for standardised and easy measurement of plant functional traits worldwide. Austria J Bot 51:335-380. doi:10. 1071/BT02124

Del Rio E, Berg A (1979) Specific leaf area of Douglas-fir reproduction as affected by light and needle age. For Sci 25:183-186

Englisch M, Starlinger F, Lin H (2011) Die Lärche-ein Baum für alle Fälle. BFW-Praxisinf 25:3-4

Geburek T (2002) Larix decidua L. Enzyklopädie der Holzgewächse Handb. und Atlas der Dendrol. Andreas Roloff, Weinheim, pp 1-20

Gholz HL, Fitz FK, Waring RH (1976) Leaf area differences associated with old-growth forest communities in the western Oregon Cascades. Can J For Res 6:49-57. doi:10.1139/x76-007

Gower ST, Richards JH (1990) Larches: deciduous conifers in an evergreen world-in their hars environments, these unique conifers support a net carbon gain similar to evergreens. Bioscience 40:818-826

Hager H, Sterba H (1985) Specific leaf area and needle weight of Norway spruce (Picea abies) in stands of different densities. Can J For Res 15:389-392

Ibrahim L, Proe MF, Cameron AD (1998) Interactive effects of nitrogen and water availabilities on gas exchange and wholeplant carbon allocation in poplar. Tree Physiol 18:481-487. doi:10.1093/treephys/18.7.481

Kilian W, Müller F, Starlinger F (1994) Die forstlichen Wuchsgebiete Österreichs_-Eine Naturraumgliederung nach waldökologischen Gesichtspunkten. Wien

Klinka K, Wang Q, Kayahara GJ et al (1992) Light-growth response relationships in Pacific silver fir (Abies amabilis) and subalpine fir (Abies lasiocarpa). Can J Bot 70:1919-1930

Koch GW, Sillett SC, Jennings GM, Davis SD (2004) The limits to tree height. Nature 428:851-854. doi:10.1038/nature02417

Lévesque M, Saurer M, Siegwolf R et al (2013) Drought response of five conifer species under contrasting water availability suggests 
high vulnerability of Norway spruce and European larch. Glob Chang Biol 19:3184-3199. doi:10.1111/gcb.12268

Lichtenthaler HK, Ač A, Marek MV et al (2007) Differences in pigment composition, photosynthetic rates and chlorophyll fluorescence images of sun and shade leaves of four tree species. Plant Physiol Biochem 45:577-588. doi:10.1016/j.plaphy.2007. 04.006

Marschall J (1975) Hilfstafeln für die Forsteinrichtung. Österreichischer Agrarverlag, Vienna

Marshall JD, Monserud RA (2003) Foliage height influences specific leaf area of three conifer species. Can J For Res 33:164-170. doi:10.1139/X02-158

Matyssek R (1986) Carbon, water and nitrogen relations in evergreen and deciduous conifers. Tree Physiol 2:177-187

Matyssek R, Schulze E-D (1987a) Heterosis in hybrid larch (Larix decidua $\times$ leptolepis $)$ I. The role of leaf characteristics. Trees Struct Funct 1:219-224

Matyssek R, Schulze E-D (1987b) Heterosis in hybrid larch (Larix decidua $\times$ leptolepsi) II. Growth characteristics. Trees Struct Funct 1:225-231

Mayer H (1977) Die Lärche (Larix decidua [europaea] Mill.). Waldbau auf Soziol.-ökologischer Grundlage, pp 22-28. Stuttgart, New York

Monserud RA, Marshall JD (1999) Allometric crown relations in three northern Idaho conifer species. Can J For Res 535:521-535. doi:10.1139/x99-015

Myers BJ, Benyon RG, Theiveyanathan S et al (1998) Response of effluent-irrigated Eucalyptus grandis and Pinus radiata to salinity and vapor pressure deficits. Tree Physiol 18:565-573

Nagel LM, O'Hara KL (2001) The influence of stand structure on ecophysiological leaf characteristics of Pinus ponderosa in western Montana. Can J For Res 31:2173-2182. doi:10.1139/ cjfr-31-12-2173

Niinemets Ü, Keenan TF, Hallik L (2015) A worldwide analysis of within-canopy variations in leaf structural, chemical and physiological traits across plant functional types. New Phytol 205:973-993. doi:10.1111/nph.13096

Oleksyn J, Modrzyński J, Tjoelker MG et al (1998) Growth and physiology of Picea abies populations from elevational transects: common garden evidence for altitudinal ecotypes and cold adaptation. Funct Ecol 12:573-590. doi:10.1046/j.1365-2435. 1998.00236.x

Oren R, Schulze ED, Matyssek R, Zimmermann R (1986) Estimating photosynthetic rate and annual carbon gain in conifers from specific leaf weight and leaf biomass. Oecologia 70:187-193. doi:10.1007/BF00379238

Perrin PM, Mitchell FJG (2013) Effects of shade on growth, biomass allocation and leaf morphology in European yew (Taxus baccata L.). Eur J For Res 132:211-218. doi:10.1007/s10342-012-0668-8

Phillips JG, Riha SJ (1993) Canopy development and solar conversion efficiency in Acacia auriculiformis under drought stress. Tree Physiol 12:137-149. doi:10.1093/treephys/12.2.137

Pierce LL, Running SW, Walker J (1994) Regional-scale relationships of leaf area index to specific leaf area and leaf nitrogen content. Ecol Appl 4:313-321
Pinheiro JC, Bates DM (2004) Mixed-effects models in S and S-PLUS, 1st editio. Springer, New York

Poorter H, Pepin S, Rijkers T et al (2006) Construction costs, chemical composition and payback time of high- and lowirradiance leaves. J Exp Bot 57:355-371. doi:10.1093/jxb/erj002

Poorter H, Niinemets Ü, Poorter L et al (2009) Causes and consequences of variation in leaf mass per area (LMA): a meta-analysis. New Phytol 182:565-588. doi:10.1111/j.14698137.2009.02830.x

R Development Core Team (2013) R: a language and environment for statistical computing. R Foundation for Statistical Computing. http://www.r-project.org/

Schober R (1949) Die Lärche: eine ertragskundlich-biologische Untersuchung. Schaper, Hannover

Smith RB, Waring RH, Perry DA (1981) Interpreting foliar analyses from Douglas as weight per unit of leaf area. Can J For Res 11:593-598

Smith WK, Schoettle AW, Cui M (1991) Importance of the method of leaf area measurement to the interpretation of gas exchange of complex shoots. Tree Physiol 8:121-127

Tardieu F, Granier C, Muller B (1999) Modelling leaf expansion in a fluctuating environment: are changes in specific leaf area a consequence of changes in expansion rate? New Phytol 143:33-43

Van Hees AFM (1997) Growth and morphology of pedunculate oak (Quercus robur $\mathrm{L}$ ) and beech (Fagus sylvatica $\mathrm{L}$ ) seedlings in relation to shading and drought. Ann des Sci For 54:9-18. doi:10.1051/forest: 19970102

White JD, Scott NA (2006) Specific leaf area and nitrogen distribution in New Zealand forests: species independently respond to intercepted light. For Ecol Manage 226:319-329. doi:10.1016/j.foreco.2006.02.001

Wieser G, Hecke K, Tausz M, Matyssek R (2013) Foliage type specific susceptibility to ozone in Picea abies, Pinus cembra and Larix decidua at treeline: a synthesis. Environ Exp Bot 90:4-11. doi:10.1016/j.envexpbot.2012.09.013

Wilson PJ, Thompson K, Hodgson JG (1999) Specific leaf area and leaf dry matter content as alternative predictors of plant strategies. New Phytol 143:155-162

Withington JM, Reich PB, Oleksyn J, Eissenstat DM (2006) Comparisons of structure and life span in roots and leaves among temperate trees. Ecol Monogr 76:381-397. doi:10.1890/ 0012-9615(2006)076[0381:cosals]2.0.co;2

Xiao C-W, Janssens IA, Yuste JC, Ceulemans R (2006) Variation of specific leaf area and upscaling to leaf area index in mature Scots pine. Trees-Struct Funct 20:304-310. doi:10.1007/s00468-005$0039-x$

ZAMG (2014) Zentralanstalt für Meterologie und GeodynamikKlimadaten 1971-2000. http://www.zamg.ac.at/fix/klima/oe7100/klima2000/klimadaten_oesterreich_1971_frame1.htm 